\title{
Dinamika Sistem Sosial Masyarakat Pedesaan di Masa Pandemi Covid-19
}

\author{
Dina Vebiola Saraswati Kuntardi \\ Universitas Islam Negeri Sunan Kalijaga \\ Pos-el: dinavebiola.saraswati@gmail.com
}

\section{DOI: $10.32884 /$ ideas.v\% vi\%i.315}

\begin{abstract}
Abstrak
Masyarakat sebagai suatu sistem akan selalu mengalami perubahan sesuai dengan tuntutan yang ada. Hal ini juga tidak terlepas pada masyarakat pedesaan yang harus berdampingan dengan covid-19 yang menerapkan aturan protokol kesehatan. Oleh sebab itu, penelitian ini ditujukan untuk mengetahui bagaimana dinamika sistem sosial budaya masyarakat pedesaan di masa pandemi covid-19. Penelitian ini merupakan penelitian kualitatif deskriptif dan dianalisis dengan skema AGIL pada teori struktural fungsional Talcott Parsons. Hasilnya menunjukkan bahwa masyarakat sebagai suatu sistem melakukan adaptasi terhadap kebijakan protokol kesehatan, membangun tujuan bersama untuk menekan laju penyebaran virus, meningkatkan rasa solidaritas sosial, dan sebagai upaya pemeliharaan terlihat adanya kegiatan operasi masker untuk selalu menerapkan protokol kesehatan.
\end{abstract}

\section{Kata kunci}

Dinamika sosial, masyarakat pedesaan, pandemi Covid-19

\begin{abstract}
Society as a system will always change according to existing demands. This is inseparable from rural communities who must co-exist with Covid-19 and apply health protocol rules. Therefore, this study aims to determine the dynamics of the social culture system of rural communities during the Covid-19 pandemic. This research is a descriptive qualitative study and analyzed by the AGIL scheme on Talcott Parsons' functional structural theory. The results show that the community as a system adapts to health protocol policies, builds a common goal to reduce the rate of spread of the virus, increases a sense of social solidarity, and as an effort to maintain, it is seen that mask surgery activities always apply health protocols.
\end{abstract}

Keywords

Social dynamics, rural communities, the Covid-19 pandemic

\section{Pendahuluan}

Pandemi covid-19 telah mendera Indonesia hampir satu tahun lamanya. Per 28 Januari 2021, sudah tercatat kasus terpapar covid-19 di Indonesia mencapai 1.037.993 dan 29.331 orang di antaranya meninggal dunia, sementara pasien yang sembuh dari covid-19 mencapai 842.122 orang (Satgas Penanganan Covid-19, 2021b). Jumlah tersebut bahkan mengantarkan Indonesia menduduki peringkat ke-19 di dunia setelah peringkat pertama diduduki oleh Amerika Serikat dengan jumlah kasus covid-19 mencapai 26.338.607 kasus (Worldometers, 2021). 


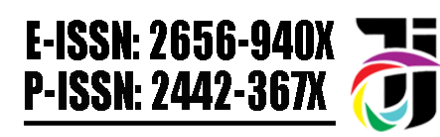

URL: jurnal.ideaspublishing.co.id
Volume:7

Nomor :1

Bulan : Februari

Tahun :2021

Pada awalnya, penularan covid-19 banyak terjadi di wilayah perkotaan, khususnya kotakota besar. Seperti DKI Jakarta yang per 28 Januari 2021 masih berada di tingkat pertama sebagai daerah dengan kasus covid-19 terbanyak di Indonesia yakni mencapai 259.305 kasus (Satgas Penanganan Covid-19, 2021b). Jumlah tersebut setara dengan 25\% kasus covid-19 di Indonesia. Namun, kini covid-19 tidak hanya menyebar di wilayah perkotaan saja, tetapi juga turut mewabah hingga ke pelosok desa. Meskipun wilayah perkotaan masih menjadi wilayah dengan tingkat penularan tinggi, bukan berarti masyarakat di pedesaan tidak memiliki risiko terhadap penularan covid-19.

Masyarakat desa dikenal sebagai kelompok yang memiliki tingkat interaksi solidaritas sosial yang tinggi, kontrol sosial yang ketat melalui nilai dan norma, serta tradisi lokal masyarakat yang kuat (Ritzer \& Goodman, 2004). Misalnya, dalam masyarakat di Desa Ngogri Megaluh Jombang, tradisi sedekah desa merupakan tradisi turun temurun yang menyiratkan pesan solidaritas, seperti wujud dari bentuk kebersamaan, kerukunan, guyub rukun/kekompakkan, dll. (Kumalasari, 2017). Sementara itu, tradisi turun temurun lainnya juga dilestarikan di Desa Gupolo Ponorogo yakni yasinan. Yasinan tidak hanya sekedar sebagai acara keagamaan tetapi juga sebagai ajang untuk meningkatkan interaksi sosial masyarakat desa (Susanti, 2020). Seperti halnya dalam budaya Jawa, budaya gotong royong tidak hanya sekedar untuk bekerja bersama namun juga dimaksudkan sebagai ruang pertemuan sosial. Ruang pertemuan sosial tersebut dibangun karena adanya kebutuhan dari setiap manusia untuk selalu mengadakan hubungan dengan orang lain, menjalin relasi, dan selalu membutuhkan orang lain. Oleh karena itu, disebutlah manusia itu sebagai makhluk homo social (Daud, 2020).

Sejak terjadi pandemi Covid-19, anjuran untuk melakukan social distancing menjadi sangat familiar didengar. Social distancing ini diyakini ampuh untuk menekan laju penyebaran Covid-19. Melakukan social distancing berarti tidak berkumpul di keramaian, tidak berkontak fisik secara langsung, serta menjaga jarak saat bertemu dengan orang lain (Daud, 2020).

Jika dilihat dari relasinya, maka aturan social distancing ini berbanding terbalik dengan kodrat manusia sebagai homo social. Inilah kemudian terjadi perubahan kondisi sosial budaya di tengah masyarakat desa. Pada awalnya menekankan hidup untuk saling bertemu dan bertatap muka sebagai esensi dari kebersamaan dan kekompokkan. Namun kini kebiasaan 
tersebut harus bersinggungan bahkan bergesekan dengan aturan-aturan yang tercantum dalam protokol kesehatan, seperti menjaga jarak. Oleh sebab itu, artikel ini mencoba untuk memberikan pandangan baru bahwa masyarakat pedesaan bukanlah masyarakat yang kaku terhadap tradisi, tetapi masyarakat pedesaan juga merupakan masyarakat yang mampu untuk berdinamika dengan menegosiasikan sistem sosial budaya agar terus dapat survive di tengah pandemi Covid-19.

Kabupaten Magelang merupakan salah satu kabupaten di Jawa Tengah yang berada di zona yang memiliki risiko tinggi covid-19 (Satgas Penanganan Covid-19, 2021a). Per 28 Januari 2021, jumlah kasus covid-19 di Kabupaten Magelang mencapai 7.689 dan 327 kasus diantaranya berasal dari Desa Grabag. Desa yang memiliki jumlah penduduk terbanyak kedua di Kabupaten Magelang ini sempat menjadi penyumbang terbanyak untuk kasus covid-19 di Kabupaten Magelang yakni mencapai penambahan 40 kasus pada 22 November 2020 silam (Ferri, 2020). Padatnya penduduk dan tingginya kasus covid-19 di Desa Grabag ini akan memungkinkan terjadinya dinamika pada sistem sosial budaya di Desa Grabag.

\section{Metode}

Penelitian ini dilakukan dengan menggunakan metode penelitan kualitatif deskriptif. Menurut Bogdan dan Taylor, penelitian kualitatif merupakan prosedur penelitian yang menghasilkan data deskriptif berupa kata-kata tertulis atau lisan dari orang-orang dan perilaku yang dapat diamati (Suwendra, 2018).

Penelitian ini dilakukan di Desa Grabag, Kabupaten Magelang, Jawa Tengah. Teknik yang digunakan untuk mengumpulkan informasi dalam penelitian ini yaitu wawancara, observasi, dan studi dokumentasi. Wawancara dilakukan kepada RT, RW, dan lima warga sebagai perwakilan masyarakat Desa Grabag. Kemudian observasi dilakukan dengan melihat pola interaksi dan komunikasi yang mencerminkan dinamika sistem sosial masyarakat selama terjadi pandemi covid-19 di Desa Grabag. Sementara itu, studi dokumentasi dilakukan dengan mengakses buku-buku, jurnal, maupun website yang dapat membantu memperkaya informasi terkait dengan dinamika sosial budaya, masyarakat pedesaan, pandemi covid-19, dll.

Data yang diperoleh melalui wawancara, observasi, maupun studi dokumentasi diolah dan dianalisis dengan menggunakan teori struktural fungsional Talcott Parsons. Parsons melihat bahwa terdapat empat imperatif fungsional sebagai ciri suatu sistem yang kemudian 


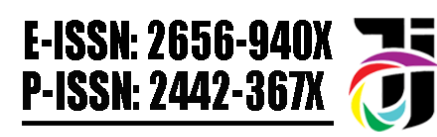

URL: jurnal.ideaspublishing.co.id
Volume:7

Nomor : 1

Bulan : Februari

Tahun :2021

dikenal dengan skema AGIL yaitu Adaptation/adaptasi, Goal attainment/pencapaian tujuan, Integration/integrasi, dan Latency/pemeliharaan. Dengan teori tersebut, dinilai dapat menajamkan analisis data dalam penelitian ini yaitu untuk melihat bagaimana dinamika sistem sosial budaya masyarakat pedesaan di masa pandemi covid-19.

\section{Hasil dan Pembahasan \\ Hasil}

Masyarakat Desa Grabag sebagai masyarakat Jawa memegang teguh prinsip "ora obah ora mamah, ora ubet ora ngliwet". Prinsip tersebut memiliki makna bahwa jika tidak bekerja/berusaha maka ia tidak akan bisa makan/memenuhi kebutuhan hidupnya. Oleh sebab itu, masyarakat akan berupaya untuk bekerja hingga merantau jauh dari kampung halaman untuk mendapatkan penghasilan. Seperti di Desa Grabag, banyak warganya yang berprofesi sebagai pedagang di pasar dan menjadi buruh harian lepas hingga ke luar Pulau Jawa.

Setelah mewabahnya covid-19 di wilayah pedesaan seperti di Desa Grabag, maka anjuran menerapkan protokol kesehatan sangat digencarkan. Namun, aturan tersebut kemudian berbenturan dengan kebiasaan yang terjadi di Desa Grabag. Banyak masyarakat yang kemudian pro dan kontra dengan aturan protokol kesehatan. Meski demikian, konflik yang terjadi di Desa Grabag tidak terjadi berlarut-larut. Seiring dengan berjalannya waktu, masyarakat Desa Grabag mengubah perilaku sosialnya dengan mulai menegosiasikan sistem sosial budaya dengan kondisi pandemi covid-19 saat ini. Hal ini dilakukan agar masyarakat tetap dapat menjalani aktivitas sosialnya dan bertahan di tengah pandemi.

\section{Berkurangnya kegiatan kerumunan}

Masyarakat di Desa Grabag merupakan masyarakat yang masih memegang prinsip solidaritas sosial dan memegang teguh adat istiadat. Seperti adanya kegiatan kerja bakti/gotong royong desa yang biasanya dilakukan setiap hari Minggu untuk membersihkan desa, masjid, dll. Kemudian kegiatan-kegiatan keagamaan seperti acara pengajian atau yasinan yang masih diselenggarakan mulai dari tingkat RT maupun RW. Kegiatan lainnya seperti dalam kegiatan PKK tingkat RW, dusun, dan desa, syukuran pernikahan, kelahiran, kenduri, tahlilan, takziyah, pengajian, dll. masih dilaksanakan oleh masyarakat setempat.

Namun, kegiatan tersebut tidak mungkin dilaksanakan sebagaimana sebelum terjadi pandemi covid-19. Banyak hal yang akan dilanggar jika tetap menyelenggarakan kegiatan 
tersebut, salah satunya yaitu aturan untuk menjaga jarak. Seperti yang dikatakan oleh masyarakat Desa Grabag berikut ini.

"Saiki ora oleh rame-rame, kudu nganggo masker. Kadang ana operasi masker, ngelingke sing podo lali nganggo masker."

(Sekarang tidak boleh ramai-ramai, harus mengenakan masker. Terkadang ada operasi masker untuk mengingatkan yang tidak memakai masker.)

Meski merasa sedikit kecewa, namun masyarakat Desa Grabag kemudian bernegosiasi dengan keadaan. Langkah yang dilakukan ialah dengan tetap menyelenggarakan kegiatankegiatan sosial di atas, namun dengan membatasi jumlah warga yang hadir. Kehadiran warga tersebut juga diwajibkan untuk mengenakan masker. Ketertiban masyarakat untuk mengenakan masker juga didukung dengan adanya kontrol/pengawasan seperti dengan adanya operasi masker yang bertujuan mengingatkan masyarakat untuk selalu mengenakan masker.

\section{Berkurangnya Intensitas Kontak Fisik}

Berjabat tangan merupakan salah satu contoh kegiatan kontak fisik yang sering dilakukan oleh masyarakat Desa Grabag saat saling bertemu. Kegiatan jabat tangan dianggap sebagai bentuk penyambutan dan penghormatan. Oleh sebab itu, hampir di setiap pertemuan warga akan berjabat tangan dengan warga lain. Bahkan biasanya kepada sesama perempuan/sesama ibu-ibu juga melakukan cium pipi kanan dan kiri.

Ketika terjadi pandemi covid-19, maka kebiasaan berjabat tangan hingga cium pipi ini mulai dihindari untuk meminimalisasi penyebaran virus. Oleh karena itu, sebagai gantinya masyarakat Desa Grabag akan menunjukkan gerakan namaste/gerakan mengatupkan kedua tangan di dada sebagai pertanda salam.

"Sekarang jarang orang-orang bersalaman. Cukup begini saja (mempraktikkan gerakan namaste)."

Langkah ini sudah terlihat cukup lumrah di kalangan masyarakat Desa Grabag. Namun, jika orang lain sudah telanjur mengulurkan tangannya untuk jabat tangan, maka akan tetap disambut dengan jabat tangan pula. Rasa pekewuh/tidak enak masih melekat di hati masyarakat. Dengan catatan, setelah kegiatan jabat tangan akan diikuti dengan cuci tangan/ menggunakan handsanitizer. 
E-ISSH: 2656-940X 굴

URL: jurnal.ideaspublishing.co.id
Volume:7

Nomor :1

Bulan : Februari

Tahun :2021

\section{Melonggarnya Nilai-Nilai Kesopanan dan Kepantasan}

Penilaian pantas dan tidak pantas serta baik dan buruk masih sangat diperhatikan di kalangan masyarakat Desa Grabag. Seperti halnya menyambut kedatangan tamu dengan berjabat tangan hingga saat berbicara dengan orang lain harus memperlihatkan wajah. Tindakan tersebut dianggap sebagai cerminan dari kesopanan. Salah seorang warga Desa Grabag mengatakan sebagai berikut.

"Nek ono dayoh, disalami. Nek omong-omongan, raine ora oleh ditutup. Kuwi jenenge unggah ungguh."

(Jika ada tamu, maka segera bersalaman. Jika mengajak berbicara, perlihatkan wajah. Itu namanya sopan santun.)

Setelah terjadi covid-19, yang terjadi ialah menghindari berjabat tangan dan wajib mengenakan masker. Menolak berjabat tangan dan mengenakan masker saat berbicara dengan orang lain bukan lagi dianggap sebagai tindakan tidak sopan/tidak pantas.

"Saiki nganggo masker lan ora salaman kuwi wis biasa. Malah kudune ngono, ben ora ketularan corona"

(Sekarang memakai masker dan tidak bersalaman adalah hal biasa. Bahkan harusnya begitu, agar tidak tertular corona)

Berdasarkan pernyataan di atas, maka dapat diketahui bahwa tolok ukur kesopanan kini tidak lagi dinilai dari cara menyambut orang lain dengan berjabat tangan dan memperlihatkan wajah saat berbicara. Oleh karena itu, masyarakat tidak lagi mengkhawatirkan ketidaksopanannya akibat menggunakan masker/menolak berjabat tangan.

\section{Pembahasan}

Manusia dan kehidupannya bersifat dinamis. Artinya, perkembangan dan perubahan akan dialami dalam kehidupan setiap manusia. Manusia yang takut berubah akan merasakan bahwa perubahan merupakan ancaman. Sebaliknya, bagi manusia yang berani dan percaya diri, perubahan justru menyenangkan dan memberi inspirasi (Purwasih, Janah, Gumilar, \& Kusumantoro, 2018). Menurut Macions, perubahan sosial merupakan transformasi dalam organisasi masyarakat dalam pola pikir dan perilaku pada waktu tertentu. Sementara itu, menurut Ritzer perubahan sosial mengacu pada variasi hubungan antarindividu, kelompok, organisasi, kultur, dan masyarakat pada waktu tertentu (Sztompka, 2017).

Masyarakat dipaksa untuk siap menerima perubahan-perubahan akibat pandemi covid-19 ini. Meskipun demikian, masyarakat pada dasarnya memang akan selalu mengalami 
perubahan. Masyarakat tidak bisa dibayangkan sebagai keadaan yang tetap, melainkan sebagai proses yang senantiasa berubah dengan derajat kecepatan, intensitas, irama, dan tempo yang berbeda (Sztompka, 2017).

Dalam konteks perubahan sosial budaya di masa pandemi Covid-19, di Jawa Tengah telah menggalakan dan melakukan "jogo tonggo". Jogo yang berarti menjaga dan tonggo berarti tetangga, maka jogo tonggo diartikan sebagai saling menjaga tetangga. Kebijakan ini diimplementasikan pada tingkat Rukun Warga (RW) dan melibatkan langsung warga setempat untuk saling menjaga tetangga. Kegiatan jogo tonggo ini dilakukan dengan mengakomodasi kearifan lokal masyarakat Jawa. Sehingga pada perkembangannya mampu meningkatkan kesadaran dan ketaatan warga untuk mematuhi protokol kesehatan (Arditama \& Lestari, 2020).

Sehubungan dengan penelitian yang telah dilakukan sebelumnya, artikel ini ditujukan untuk menambah kontribusi dalam memberikan pandangan baru dalam memotret fenomena perubahan sosial budaya masyarakat desa di tengah pandemi Covid-19. Yakni melihat fleksibilitas masyarakat pedesaan dalam berdinamika dengan sistem sosial budaya dan tuntutan untuk mematuhi protokol kesehatan.

Masyarakat diibaratkan sebagai sistem sosial yang di dalamnya terdiri dari bagianbagian maupun elemen yang saling berkaitan, saling memengaruhi, dan menyatu dalam menciptakan sebuah keseimbangan. Menurut Talcott Parsons yang dikenal sebagai tokoh fungsionalisme struktural, bahwa terdapat empat imperatif fungsional yang diperlukan atau menjadi ciri suatu sistem yang kemudian dikenal dengan skema AGIL (AAdaptation/Penyesuaian, G-Goal attainment/Pencapaian Tujuan, I-Integration/Integrasi, dan L-Lantency/Pemliharaan Pola). Agar dapat bertahan hidup, maka sistem harus menjalankan keempat fungsi tersebut (Ritzer \& Goodman, 2004). Dengan kata lain, fungsi-fungsi tersebut harus dipenuhi dalam sebuah sistem untuk kelestarian sistem tersebut. Seperti halnya pada masyarakat Desa Grabag, agar dapat bertahan dan hidup berdampingan dengan covid-19, maka keempat fungsi AGIL tersebut haruslah dipenuhi. Berikut pembahasannya.

\section{Adaptation/ Adaptasi}

Sebuah sistem harus mengatasi kebutuhan situasional yang datang dari luar. Ia harus beradaptasi dengan lingkungan dan menyesuaikan lingkungan dengan kebutuhankebutuhannya (Ritzer \& Goodman, 2004). Ketika anjuran protokol kesehatan dan edukasi 


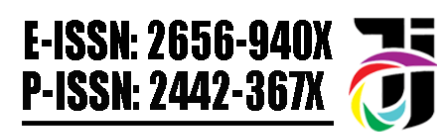

URL: jurnal.ideaspublishing.co.id
Volume:7

Nomor : 1

Bulan : Februari

Tahun :2021

kepada masyarakat semakin digencarkan, maka muncul sebuah kesadaran dan merujuk pada perilaku adaptasi. Seperti yang terlihat di Desa Grabag, sudah mulai terbiasa masyarakat mengganti jabat tangan dengan gerakan namaste, menggunakan masker saat bertemu dengan banyak orang, mengurangi dan menghindari kegiatan kerumunan, dan melonggarnya aturan kesopanan dan kepantasan.

Selain itu, beberapa kegiatan sosial masyarakat juga dimanipulasi agar gesekan diantara masyarakat tidak terlalu tajam. Seperti penyelenggaraan tahlilan, takziyah, yasinan, syukuran, kenduri dll. Jika benar-benar ditiadakan seluruhnya, maka akan banyak masyarakat yang menentang karena kegiatan tersebut merupakan bagian dari tradisi yang sudah turun temurun. Oleh sebab itu, bentuk manipulasi yang dilakukan yakni dengan menyelenggarakan kegiatan tahlilan, takziyah, yasinan, syukuran, kenduri dll., tetapi dengan adanya pembatasan warga yang hadir, adanya himbauan untuk menjaga jarak, wajib mengenakan masker, serta mencuci tangan saat datang dalam kegiatan tersebut.

\section{Goal Attainment/ Pencapaian Tujuan}

Sebuah sistem harus mendefinisikan dan harus mencapai tujuan utamanya (Ritzer \& Goodman, 2004). Terciptanya suatu tujuan tentunya akan diawali dengan terbentuknya kesadaran masyarakat. Kesadaran tersebut tidak hanya mengarah pada kesadaran pribadi, melainkan kesadaran bersama dalam suatu masyarakat. Bentuk perilaku adaptasi yang telah dilakukan oleh masyarakat Desa Grabag merupakan suatu bentuk kesadaran untuk bersamasama menanggulangi penyebaran covid-19. Dengan mematuhi protokol kesehatan, artinya bahwa masyarakat Desa Grabag turut berpartisipasi dalam menekan laju penyebaran covid-19, khususnya di wilayah pedesaan.

\section{Integration/Integrasi}

Sebuah sistem harus mengatur hubungan bagian-bagian yang menjadi komponennya termasuk harus mengatur hubungan antarketiga fungsi imperatif tersebut (A,G,L) (Ritzer \& Goodman, 2004). Integrasi dapat dicapai dengan adanya kerja sama antaranggota masyarakat. Dalam konteks sosial masyarakat pedesaan pada masa pandemi, solidaritas sosial masyarakat Desa Grabag sangat diperlukan untuk menghambat penyebaran covid-19. Selain itu, upaya pengawasan juga diperlukan untuk me-monitoring perilaku masyarakat. Upaya pengawasan ini terlihat dengan adanya operasi masker di Desa Grabag seperti di pasar maupun di beberapa titik jalan yang ramai lalu lintas masyarakat. 


\section{Latency}

Sebuah sistem harus melengkapi, memelihara, dan memperbarui motivasi individu dan polapola budaya yang menciptakan dan mempertahankan motivasi tersebut (Ritzer \& Goodman, 2004). Perilaku yang ditunjukkan masyarakat Desa Grabag yang tidak bersalaman, menggunakan masker, membatasi kegiatan sosial, dll. pada suatu titik akan merasa jenuh dan letih, sebab dilakukan dalam kurun waktu yang lama bahkan tidak mengetahui akan sampai kapan covid-19 ini akan berlalu. Oleh sebab itu, maka perlu adanya pembaruan motivasi dan memperkuat komitmen.

\section{Simpulan}

Berdasarkan uraian di atas, maka dapat disimpulkan bahwa masyarakat sebagai suatu sistem akan lestari jika mampu menghadapi tuntutan yang ada. Oleh karena itu, masyarakat akan berdinamika sesuai dengan kondisi dan situasi saat itu. Seperti halnya pada saat pandemi covid-19, masyarakat dituntut untuk dapat mengikuti anjuran menerapkan protokol kesehatan sebagai bentuk partisipasi dalam menanggulangi penyebaran covid-19. Tidak terlepas pada masyarakat pedesaan yang kental dengan solidaritas dan adat istiadatnya. Oleh sebab itu, masyarakat Desa Grabag berproses melalui adaptasi, bersama-sama mendefinisikan tujuan perubahan, berintegrasi, dan menjaga pola perubahan dalam sebuah tatanan yang masyarakat dapat hidup berdampingan dengan covid-19.

\section{Saran}

Penilitian ini diharapkan dapat memberikan kontribusi dalam aspek sosial budaya, khusunya dalam melihat dan mencerna fenomena yang terjadi di tengah terjadinya pandemi Covid-19 dalam masyarakat desa. Meski demikian, di lapangan masih terdapat banyak sekali realitas yang perlu diangkat dan dibahas secara ilmiah. Diantaranya yakni tentang pandemic fatigue atau kelelahan dalam menghadapi Covid-19. Hal ini dilatarbelakangi oleh adanya ketidakpastian akan berakhirnya pandemi Covid-19.

\section{Daftar Pustaka}

Arditama, E., \& Lestari, P. (2020). Jogo Tonggo: Membangkitkan Kesadaran dan Ketaatan Warga berbasis Kearifan Lokal pada Masa Pandemi Covid-19 di Jawa Tengah. Jurnal Pendidikan Kewarganegaraan Undiksha, 8(2), 157-167. Retrieved from https://ejournal.undiksha.ac.id/index.php/JJPP. 


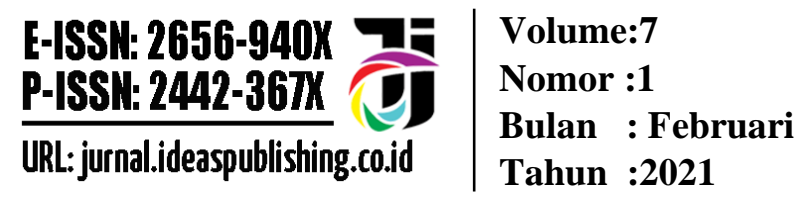

Daud. (2020). Social Distancing dan Budaya Kita. Medan. Retrieved from https://www.researchgate.net/publication/341218892.

Ferri, R. (2020). Peta Sebaran Kasus Covid-19 di Kabupaten Magelang, Kasus Baru Tambah 171, Terbanyak Kecamatan Grabag Artikel ini telah tayang di Tribunjogja.com dengan judul Peta Sebaran Kasus Covid-19 di Kabupaten Magelang, Kasus Baru Tambah 171, Terbanyak Kecamatan Gra.

Kumalasari, L. D. (2017). Makna Solidaritas Sosial dalam Tradisi "Sedekah Desa" (Studi pada Masyarakat Desa Ngogri Megaluh Jombang) Luluk Dwi Kumalasari. In Research Report (Vol. 0). Malang. Retrieved from http://researchreport.umm.ac.id/index.php/research-report/article/view/1336.

Purwasih, J. H. G., Janah, Y. E., Gumilar, F. R., \& Kusumantoro, S. M. (2018). Ensiklopedia Sosiologi Perubahan Sosial. Klaten: Cempaka Putih.

Ritzer, G., \& Goodman, D. J. (2004). Teori Sosiologi Modern. Yogyakarta: Kreasi Wacana. Satgas Penanganan Covid-19. (2021a). Peta Risiko.

Satgas Penanganan Covid-19. (2021b). Peta Sebaran COVID-19.

Susanti, F. (2020). Kegiatan Rutinan Yasinan Dan Tahlilan Untuk Meningkatkan Interaksi Sosial Masyarakat (Studi Kasus Di Desa Gupolo, Babadan, Ponorogo).

Suwendra, I. W. (2018). Metodologi Penelitian Kualitatif dalam Ilmu Sosial, Pendidikan, Kebudayaan dan Keagamaan (I. B. A. L. Manuaba, Ed.). Bali: Nilacakra.

Sztompka, P. (2017). Piotr Sztompka (8th ed.). Jakarta: Kencana.

Worldometers. (2021). Covid-19 Coronavirus Pandemic. 